\title{
Analysis on the Ecological Evolution Mechanism of Social Enterprises from the Perspective of Social Governance*
}

\author{
Feng Xiao \\ Sichuan Technology and Business University \\ Chengdu, China 611745
}

\begin{abstract}
Social enterprise is a kind of new organization mode appearing in the middle and late twentieth century. It is a mixed organization between commercial enterprises and non-profit organizations, with dual objectives of creating economic and social values. In the face of traps of "three failures" in government, market and society, the distinctive advantages of social enterprises will reveal completely. From the perspective of social governance, this thesis deeply analyzes the ecological evolution mechanism of social enterprises on the basis of exploring many social and economic problems that exists in China.
\end{abstract}

Keywords-social enterprise; social governance; ecological evolution mechanism

\section{INTRODUCTION}

After experiencing reform and opening up of many years, economy develops rapidly and the speed of social transformation also accelerates, and the social development of China has shown a brand new pattern: division of social benefits, the diversified values, the germination of civil society, the atomization of social organization, the popularization of social media, the lack of social participation, imbalance of social psychology, frequent group events, the decline of government image and so on. To deal with these facing problems in new era, from the perspective of social development and evolution, we should improve the modernization of social governance, in other words, we should clarify the relationship between government, market and society, and finally build a public governance system coordinated and governed by the three of government, market and society.

Under normal conditions, if the market mechanism operates well, even without the intervention of government, the market itself also can play a good role in allocating resources to meet the demands of people for production and

*Scientific research project of Sichuan provincial education department in 2015-An Empirical Study on the Factors of Affecting the Operation of Social Enterprise (Project Number: 15SB0382); The 2016 annual scientific research project of Zigong Federation of Social Sciences-Study on the Path of the Transformation of Zigong Public Welfare Organization into Social Enterprise (Project Number: 2016D18); The 2016 annual scientific research project of Sichuan Technology and Business University-Study on Business Models of Social Enterprise in Meishan (Project Number: 2016RYB34X). life. In a particular case, the phenomenon of market failure will occur due to public products, externality, asymmetric information, economic monopoly and other reasons. Therefore, it is necessary for the government to apply public policy to address the problems. However, due to the problems of democratic voting system, bureaucracy system, entrusted agency, rent-seeking and corruption, government also has the problems of failure, so it cannot entirely rely on government to address the problems. Moreover, the worse situation is that the market failures and government failures exist at the same time, and it is necessary to solve the existing problems of market and government through social mechanism. However, the social mechanism is not a panacea if social members generally lack justice, belief and autonomous power, and even present all the silence and blind, and all the problems are left to market and government to dispose, so social failure will generate.

In today's China, the challenges that we are facing are: not only need we to address the problems of "three failures" in traditional market, government and society, but also solve the problems of immature market, faulty government and insufficient development of society in the transition period of China.

According to the concept of governance in modern society, solving the social public problems will not just rely on one of the three branches: government, market and society. All kinds of private and public organization will jointly exert their own mechanism advantages to solve social problems and defuse social conflicts. Based on this idea, the corporate social responsibility movement began to rise in the western developed countries since the middle of twentieth century; by the end of twentieth century, social enterprises had gradually become the emerging subject of diversified social governance.

Social enterprise as a kind of new organization form, at present, there is no unified concept in all walks of life. The most widely used definition of social enterprise is put forward in 2004 by the UK Department of Trade and Industry. It proposed that social enterprises are "those enterprises with certain social targets and the profits are mainly invested in their business itself or community according to their social goals, and not make profits for 
enterprise shareholders and possessors". " This definition emphasizes the non-profit purpose of the organization and the methods of reinvestment in surplus, which is the significant characteristic of social enterprise which is different from the commercial enterprise and non-profit organization. Therefore, social enterprise is not just for profit and charity, but to achieve a certain social mission by organically combining the social purposes with commercial means. This feature makes social enterprise become a new favorite in the field of social governance.

\section{THE GROWTH SOIL OF SOCIAL ENTERPRISES}

To better study the growth soil of social enterprises, the author will apply the theory of state and society relations ${ }^{2}$ to carry out a depth analysis. The theories of state and society relations mainly include the theory of civil society, pluralism, corporatism and so on.

The concept of Civil Society was put forward by Aristotle in his Political Science. It was originally used to describe the system that citizens could freely and equally participate in political activities in the ancient Greek. The concept of society and state had not diverged at that time, after a long period of the middle ages, and the civil society had been mentioned again with the establishment of capitalist system. Hegel gave a clear definition to the concept of state and society in his Elements of the Philosophy of Right, and he put forward the theoretical framework of "state is higher than civil society" and clearly pointed out that society was subordinate to the state; on the contrary, Rock, a famous liberalism thinker, built the theoretical framework of "civil society precedes or is out of the state" and pointed out that society was in parallel with the state. ${ }^{3}$ Although the two have opposing views, they have jointly established the twopart model of "state-society". With the adjustment and differentiation of social structure, the two-part model seems to be no longer harmonious. In 1992, the American scholar Cohen and Arato clearly put forward the three-part model of "state-society-economy" in their coauthored book named The Civil Society and Political Theory, which provides a theoretical model for further deconstructing social components and researching on social elements.

In the theory of civil society, whether it is the two-part model or three-part model, there is an argument focus: which is the dominant factor in the relationship of state and society? Polyphyletism and Corporatism provide a new theoretical perspective on this issue.

Polyphyletism inherits Rock's theory tradition of "civil society precedes or is out of the state". They believed that the state is embedded in social political organizations, and social organizations are highly differentiated and various powers are highly dispersed. Therefore, organizations scatter here and there in society, and there is no organization with

\footnotetext{
${ }^{1}$ DTI.Social Enterprise: a Strategy for Success [R].London: Department of Trade and Industry, 2002.

${ }^{2}$ Here, the state is a political concept, and refers to government agencies, however, society is on the opposite side and refers to a non-official field.

${ }^{3}$ Deng,Zhenglai. Civil Society and the State -- the Dividing Line and Two Framework in Theory[J]. Social Science Journal, 1993(5)
}

absolute authority. Under the value of "liberalism", polyphyletism especially emphasizes opposition and competition, so as to achieve a social equilibrium through mutual checks and balances among organizations.

Corporatism inherits Hagel's theory legacy of "state is higher than civil society", which is the theoretical model for the interests of the group. Under the corporatism system, various social organizations are absorbed into the state system and have legal connection ways with the government. Therefore, corporatism especially emphasizes stability and integration. According to the power comparison between state and society, corporatism can be further divided into state corporatism and society corporatism. The former emphasizes the dominant forces of the country and the later emphasizes the leading forces of the society.

As a result, it can be seen that the growth condition of social enterprises basically depends on the state pattern of various countries. The so-called state pattern is that "we summarize the state into the multiple stable equilibrium of the general political exchange game in the political domain, in which some orders will be reached between the government and the private." 4 In the theory of the relationship between state and society, the types of governance mechanism of private domain and state domain mainly present as the three forms: the state corporatism, social corporatism and polyphyletism. Accordingly, social enterprises as a social interest's coordination mechanism with intermediateness, it presents different growth situation in different social soil. "Fig. 1" The growth of social enterprises is formed by multiple evolutions and games in the market domain, political domain and social domain, which is the product of adapting to the three national forms.

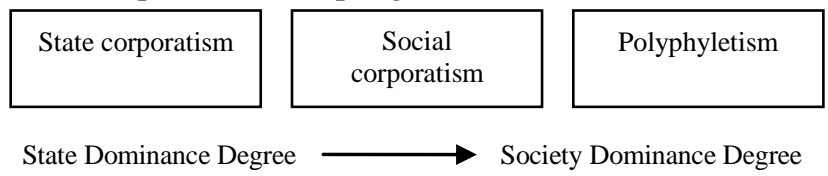

Fig. 1. Corporatism and Polyphyletism.

In terms of the current state pattern of China, it may closer to the form of state corporatism, because the thought of "state controls society" is rooted in Chinese society, and the model of "omnipotent government" is difficult to reverse completely in a short period. Overall, the dominant power of China is far better than the society. In the transition period, although the state domain is constantly shrinking and the areas of society and market are expanding, however, the government's tentacles are still very broad. According to the logic of social development, from the perspective of the current situation of China, the system of state corporatism is gradually moving to the system of polyphyletism and the growth soil of social enterprise will become wider and wider.

\footnotetext{
${ }^{4}$ Masahiko Aoki writes, Zhou Lian translates. Towards a Comparative Institutional Analysis[M]. Shanghai: Shanghai Far East Publishers, 2001:156
} 


\section{THE GROWTH PATH OF SOCIAL ENTERPRISE}

As the government gradually deregulates the control over market and society, various social organizations have sprung up and developed rapidly in China. Social enterprises first emerged from the social domain of the third sector, but the generation of the third sector benefited from the decentralization of the first sector and the nourishment of the second sector. If the government of the first sector is the father of the social enterprise, and the enterprise of the second sector is the mother of the social enterprise. Therefore, social enterprises have left a deep imprint of their parents since the birth of social enterprises.

\section{A. The "Birthmark" of Social Enterprise}

\section{1) Inherent advantage.}

First of all, social enterprises do not have the political compulsory strength possessed by the government, but have the public interest pursuit by the government. Therefore, social enterprises seem to be more flexible in social welfare work, and they are more trusted by the public. Second, social enterprises do not have the original profit seeking motivation possessed by the enterprises, but have the business operation model. Therefore, social enterprises have more material basis and economic rationality in social welfare work.

\section{2) Natural disadvantage}

First of all, in the aspect of social public affairs, social enterprises can only play a seam protector role for government department to alleviate part of failures phenomenon of government. Government is the maker of public policy and the main supplier of public services, and the effect of social enterprises in more represented by catalysts and lubricants. Second, in the aspect of economic development, social enterprises can only be the supporting role for the enterprise sector to regulate part of failures phenomenon of market. Enterprises are the main creator and distributor of social wealth, and social enterprises can realize the social purpose by business operation, but they just play a certain role in regulating the social redistribution. Finally, the financial resources of social enterprises are relatively tight and the sources are dispersive. They can neither levy tax like government which relies on its political power, nor gain high profits like enterprise through purely commercial operations.

\section{B. The "Neighbors" of Social Enterprise}

Social enterprise is a kind of mixed organization, in other words, its development targets are not unitary, which not only pursues social performance but the economic performance. If government and enterprise are the two endpoints of social performance and economic performance, and social enterprises are actually in the middle position of the two sides. "Fig. 2"

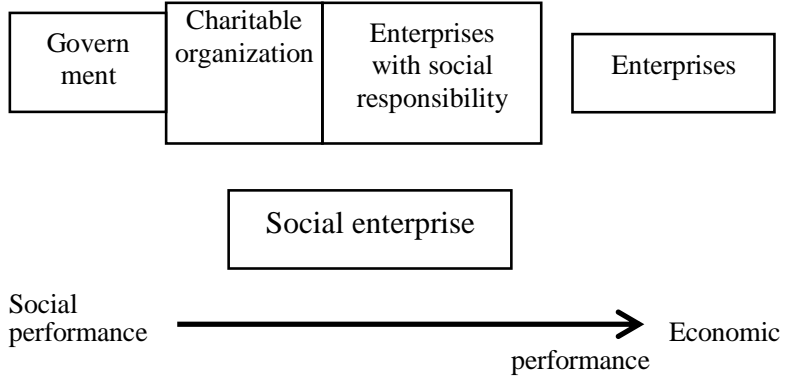

Fig. 2. The "neighbors" of social enterprise.

From the left side to right side in "Fig. 2", from the transition of focusing on social performance to economic performance, there are government, charitable organization, and social enterprise, enterprises with social responsibility and enterprise. From the distribution of this ecological chain, we can see that the organizational mission and survival style of social enterprise have received the characteristics of various organizations, with typical miscibility.

Compared with charitable organization, the human resources of social enterprises are more stable and normative; the capital sources of social enterprise are more extensive and diverse; the operation model of social enterprise is more commercial. Compared with these enterprises with social responsibility, social enterprises have a strong sense of social mission; social enterprises prefer social performance to economic performance.

In conclusion, under the background of increasing relaxed social atmosphere, the third sector has gradually enhanced in the process of making up the functional defects of the first sector and the second sector. Social enterprises are embedded in the third sector, so they are born with some genetic characteristics of government and enterprise. Furthermore, social enterprises also combine with some excellent characteristics of charitable organizations and enterprises with social responsibility, so they play a vital role in social governance system.

\section{THE ECOLOGICAL COMMUNITY OF SOCIAL ENTERPRISE}

We must deeply inspect the social enterprises which take the social mission and economic purpose into account, for the significance of social governance, and we should construct the ecological community model of social enterprises. For the dual mission of social enterprise, both of them are equally important in the aspect of theory, but they will pay attention to different fields in reality. Different types of social enterprises will have different degree of acceptance or rejection on the two kinds of missions. Therefore, according to the public welfare and marketability of the social enterprise, the author divides it into four types and establishes the ecological community model of social enterprise. "Fig. 3" 


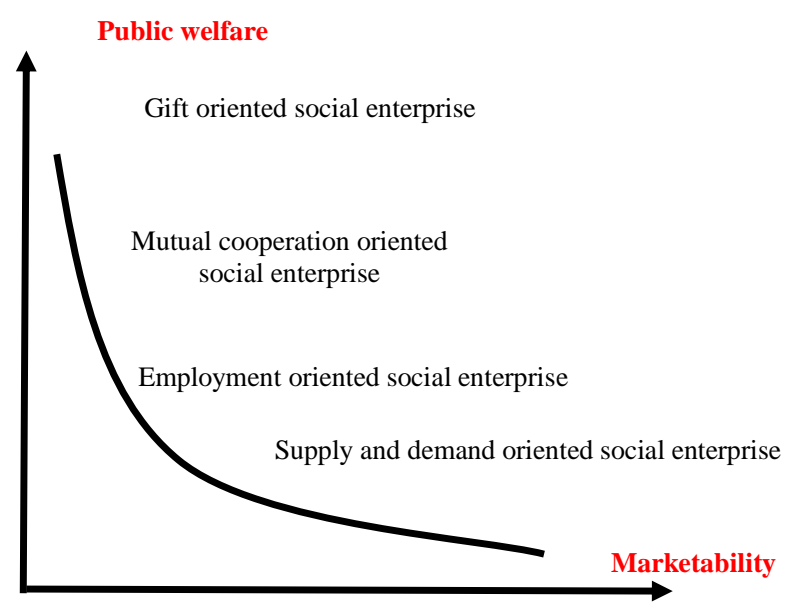

Fig. 3. Ecological community model of social enterprise.

\section{A. Gift Oriented Social Enterprise}

Gift oriented social enterprises carry out the daily operation of the enterprise through the charitable donation activity of traditional significance. This kind of enterprise operation mode does not belong to social enterprise and the more accurate expression should be named "non-profit organization". However, from the perspective of broad significance, if only they can independently, substantially and constantly carry out the relevant fund operation activities, and can also be a model of solving social problems by applying commercial intelligence. For example, launched in 2014 by former Boston College baseball player, the ALS (Amyotrophic Lateral Sclerosis) ice bucket challenge activity swept the world, and all the chiefs followed the chain named mechanism and participated in the wet challenge activity. This activity stipulated that the invited person should either accept the challenge within 24 hours or choose to donate $\$ 100$ to the groups of "gradually frozen person". Just in the United States, one million and seven hundred thousand people participated in this challenge and two million and five hundred thousand people donated money, the total amount reached one hundred and fifteen million Yuan. ${ }^{5}$ The development of this activity has attracted the public to pay close attention to this social vulnerable group and take various positive assistance measures.

\section{B. Mutual Cooperation Oriented Social Enterprise}

Mutual cooperation oriented social enterprises have the characteristics of non-profit organization at first, however, they also can carry out the activities according to the enterprise management way. They are characterized by the way of enterprise management to realize the purpose of mutual benefit and mutual benefit among the members of an enterprise. For example, in the early days of the founding of the People's Republic of China, the agricultural cooperative has some characteristics of mutual cooperation oriented

${ }^{5}$ How to spend the Two Hundred Million Donations of Ice Bucket Challenge?

[EB/OL]http://finance.sina.com.cn/world/20140827/145920136860.shtml.2 014.8 . social enterprise. Early agricultural cooperative was the small mutual cooperative organization which was spontaneously built by farmers, but the premise still was the private ownership of land, in other words, the land belonged to families and the cooperative only deployed the labor force in the busy season, even a small amount of money could be allowed in the planting season. However, in the later stage, the Chinese government irrationally promoted the development of cooperative organization and the ownership system began to change, and then the people's commune emerged, which seriously violated the laws of economy.

\section{Employment Oriented Social Enterprise}

The emphasis of employment oriented social enterprises are to solve the employment problems of some people with difficulties (former criminals, women and homeless people and so on), and they can provide them with self-reliance survival platform. This kind of enterprises utilizes fully the market mechanism of labor and employment, however, in the actual operation, and the weakness of human resources has also brought some problems to the operation enterprises. For example, Shenzhen disabled friends group as a group of high-technology enterprise takes it as the mission of enterprise that "develops the harmonious technology of society and people's livelihood and the cooperation and development of high-technology industry and puts it into modern industrial system." And this enterprise is praised as the model of entrepreneurship to promote employment. The investment operation mode is that this enterprise cooperates with local departments of technology and people's livelihood, and then the government provides the free space for several years to them. The disabled friends funds the decoration, purchase equipment, station management and technical team, develop training and other works.

\section{Supply and Demand Oriented Social Enterprise}

Supply and demand oriented social enterprises mainly provide economical and practical products and services to the special social vulnerable groups and meet their basic living demands. This kind of enterprise can avoid the moral risk of the traditional charitable organizations in the process of providing charitable donations and properly introduce market mechanism so that the enterprise audience can participate in the sharing mechanism of product-cost. For example, in the process of Chinese urbanization in recent decades, there are many schools for the children of migrant workers to spring up. Schools for the children of migrant workers meet the educational demands of some migrant children and guarantee the rights of some migrant children to receive education. Although there are various defects and wrong leakages existing in this kind of schools, under the background that the government cannot effectively provide the public educational services to the children, and this kind of educational service of low fee standard and low teaching level can also relieve the failures phenomenon of local government. 


\section{CONCLUSION}

Chinese social development has already stepped into a new norm, and the public governance problems have become increasing prominent. The problems of government failure, market failure and social failure frequently happen, so it is urgent to solve the symbiotic coexistence relationship of government, market and society. Social enterprise is a good medicine to solve this problem, and it has both social missions and commercial means and can better cope with the "three failures" phenomenon. Social enterprise is born out of the third sector and has close relationship with the first sector and the second sector, and has the deep imprint of the former. To fully exert the social governance function of social enterprises, it is necessary for us to study the ecological evolution mechanism of social enterprises such as growth soil, growth path, and ecological community and so on.

\section{REFERENCES}

[1] Miao Qing, Social Enterprises-Linking Business with Social Benefits[M]. Zhejiang University Press, 2014.

[2] Wang Shiqiang. Government Policies and Measures to Promote the Development of Social Enterprises: International Experience and China's Approach[J]. Journal of Tianjin Administration Institute, 2013(3).

[3] Sorting out the Relations of Government, Market and Society, and Improving the Modernization of the State Governance. [EB/OL]. http://finance.sina.com.cn/roll/2016-11-30/docifxyawxa3110654.shtml, 2016.11.

[4] Shi Meiping. Research on the Countermeasures of Boosting Social Enterprise Development from the Perspective of Multi-Governance[J]. Journal of Hubei Institute of Socialism, 2016(4). 